\title{
Records of crustacean decapodid stages from the family Enoplometopidae (Crustacea: Decapoda) in the pelagic environment of the western Indian Ocean
}

\author{
О находках декаподид Аесятиногих раков из семейства \\ Enoplometopidae (Crustacea: Decapoda) в жкелудках некоторых \\ хищных рыб в пелагиали западной части Индийского океана
}

\author{
Rudolf N. Burukovsky ${ }^{1}$, Evgeny V. Romanov ${ }^{2}$ \\ Рудольф Н. Буруковский ${ }^{1}$, Евгений В. Романов
}

\footnotetext{
${ }^{1}$ Kaliningrad State Technical University, 1, Sovetsky Prospect, 236022 Kaliningrad, Russia

${ }^{1}$ Калининградский государственный технический университет, Советский просп., 1, Калинингад, 236022, Россия. E-mail: burukovsky@klgtu.ru

${ }^{2}$ Centre technique de recherche et de valorisation des milieux aquatiques (CAP RUN - CITEB) 97420 Le Port, île de la Réunion E-mail: abyss.explorer.io@gmail.com
}

KEY WORDS: Crustacea, Decapoda, Enoplometopus pictus, E. holthuisi, Alepisaurus ferox, Thunnus alalunga, Thunnus albacares, decapodid, morphology description, Reunion Island.

КЛЮЧЕВЫЕ СЛОВА: Crustacea, Decapoda, Enoplometopus pictus, E. holthuisi, Alepisaurus ferox, Thunnus alalunga, Thunnus albacares, декаподид, описание морфологии, Реюньон.

ABSTRACT. Juveniles of decapod crustaceans at the decapodid stage were recorded in the stomachs of top pelagic predators (Alepisaurus ferox, Thunnus alalunga, and $T$. albacares) caught in the oligotrophic gyre of the south-west Indian Ocean. Decapodods were found partially digested in stomachs. We were able to identify them and describe their morphological characters for the first time. These juveniles belong to the genus Enoplometopus (family Enoplometopidae de Saint Laurent, 1988, superfamily Enoplometopoidea de Saint Laurent, 1988, and infraorder Astacidea Latreille, 1802). 1. Enoplometopus pictus A. Milne-Edwards, 1862. Adults are only known from the holotype of species collected in Reunion Island.Our decapodids differs by their absence of armament on the outer margin of palms and fingers of chelae, as well as an absence of tubercles on the lateral surfaces of palms of the first pereiopods chelae. 2. E. holthuisi Gordon, 1968. It differs from other Enoplometopus species which possess two post-cervical spines with very thin cheliped. The length of the chela exceeds $50 \%$ of that of pereiopods; fingers length is slightly less than chela length. The chela width is 7.5 times its length. This species differs from E. gracilipes and $E$. voigtmanni that have a similar chela shape: the absence of two spines at the dorsal rear edge of the 6th abdominal somite (present in E. gracilipes), and by distribution range (E. voigtmanni). E. holthuisi records are known in Reunion Island while no occurrences of $E$. voigtmanni were recorded in the study area. Presence of $E$. holthuisi in the waters of Mauritius Island is reported for the first time extending documented distribution of this species in the Indian Ocean.
How to cite this article: Burukovsky R.N., Romanov E.V. 2020. Records of crustacean decapodid stages from the family Enoplometopidae (Crustacea: Decapoda) in the pelagic environment of the western Indian Ocean // Arthropoda Selecta. Vol.29. No.4. P.443451. doi: 10.15298/arthsel. 29.4.06

РЕЗЮМЕ. Ювенильные особи десятиногих ракообразных на стадии декаподита были обнаружены при исследовании содержимого желудков крупных хищных рыб (Alepisaurus ferox, Thunnus alalunga и T. albacares), обитающих в пелагиали олиготрофных вод южного субтропического круговорота Индийского океана, расположенного к востоку от острова Мадагаскар. Декаподиты были в той или иной степени повреждены пищеварительными ферментами. Несмотря на это, удалось идентифицировать два вида декаподид и впервые описать некоторые особенности их морфологии. Декаподиты относятся к омароподобным десятиногим ракам из рода Enoplometopus (семейство Enoplometopidae de Saint Laurent, 1988, надсемейство Enoplometopoidea de Saint Laurent, 1988, инфраотряд Astacidea Latreille, 1802). Первый - Enoplometopus pictus A. Milne-Edwards, 1862. Взрослые представители этого вида известны лишь по голотипу вида, найденному у острова Реюньон. Декаподиты отличаются от него отсутствием вооружения на ребрах ладоней и пальцев клешней, а также бугорков на боковых поверхностях ладоней клешней первых переопод. Второй вид - декаподид E. holthuisi Gordon, 1968. Он отличается от других видов из рода Enoplome- 
topus, имеющих два постцервикальных шипа, строением клешни, если не более длинной, то значительно более узкой. Длина клешни составляет более половины длины всей конечности, длина ее пальцев несколько меньше половины длины клешни, а ее ширина - в 7,5 раза меньше длины. Он отличается от имеющих относительно длинные клешни E. gracilipes и E. voigtmanni отсутсвием двух шипов на дорсальной стороне 6 сегмента абдомена (присутствуют у E. gracilipes), и областью распространения (E. voigtmanni). E. holthuisi известен находкой у о-ва Реюньон, тогда как имаго $E$. voigtmanni в этой части океана неизвестны. Нами впервые приводится находка E. holthuisi в водах острова Маврикий, расширяя документированное распространение этого вида в Индийском океане.

\section{Introduction}

Reef lobsters of the genus Enoplometopus are widely distributed in tropical waters of the world's oceans, inhabiting shallow-water coral reef ecosystems. They are small species (maximal total length is less than 200 $\mathrm{mm}$ ) with a brightly coloured carapace. They are often on display in marine aquaria [Baensch, Debelius, 1992]; their colourful pictures are commonly shown in diving and snorkelling periodic journals and general literature focused on tropical marine fauna [Debelius, 2001]. In natural environment, however, Enoplometopus species are secretive, solitary animals that are rarely encounters during underwater observations. The current state of knowledge of the biology and ecology of these species is extremely poor, distribution of several species is known from single records, therefore any new information collected is essential. Even taxonomic position of Enoplometopus within Decapoda was disputed up until the early 2000s. Only recently were these crustaceans finally placed in the family Enoplometopidae Saint Laurent, 1988 [Saint Laurent, 1988; Martin, Davis, 2001; Chan, 2010]. Very little is known about their reproduction and growth, including data on ontogenetic morphological changes. Several development stages were partially described for the single species Enoplometopus antillensis Lütken, 1865 [Abrunhosa et al., 2007; Martin et al., 2014], and some peculiarities of juveniles' claw armament were described for E. crosnieri [Chan, $\mathrm{Ng}, 2008$ ].

Adult Enoplometopus species are benthic, their larvae are pelagic [Poupin, 2003; Martin et al., 2014] while biological and ecological preferences of postlarvae and juveniles and their settlement period are poorly known. Post-larvae of Enoplometopus are commonly reported (only identified at a generic level) from the stomachs of tropical pelagic and benthopelagic predators both in the eastern Atlantic, western Indian Ocean, Central and Western Pacific [Dragovich, 1970; Potier et al., 2004, 2007a,b, 2014; Dambacher et al., 2010; Choy et al., 2013; Williams et al., 2014; Trystram et al., 2015].
Juveniles of Enoplometopus at the decapodid stage [Martin et al., 2014] were commonly recorded during ongoing studies focused on the trophic ecology of top predators in the oligotrophic gyre of the south-west Indian Ocean within the Indian South Subtropical Gyre Province (ISSG) [Longhurst, 2007]. Here we present the identification and first morphological description of pelagic juveniles for two species from the genus Enoplometopus collected in the area. Then we will present and discuss the distribution of pelagic stages of Enoplometopus in the western Indian Ocean based on a wide range of data, using pelagic top predators such as tuna, billfish and associated species as biological samplers.

\section{Material and methods}

Data was collected independently around islands Reunion and Mauritius (southwestern Indian Ocean) during several research projects focused on the trophic ecology of top pelagic predators: tuna (Thunnus spp.), billfish (Xiphiidae and Istiophoridae), and lancetfish (Alepisaurus ferox). Predatory fish were caught during research and commercial cruises, with pelagic longline gears in offshore waters of the western Indian Ocean, and with handlines in proximity to fish aggregation devices (FADs) anchored off the northern coast of Mauritius Island at a distance 1 to 10 nautical miles from shore between 500 and $3000 \mathrm{~m}$ depth. Stomachs were collected either onboard, at the local processing plants or at landing sites (for handline fisheries). Stomachs were frozen at $-18^{\circ} \mathrm{C}$ and stored in the freezer until further processing in the laboratory. Stomachs were treated following a standard protocol described in Potier et al. [2007a,b]. All recovered individuals of the genus Enoplometopus were recorded; several specimens collected in 2012-2016 were preserved for further detailed identification: those collected off Reunion Island are indicated below as RUN, and the ones collected off Mauritius as MRU. Archival data from the STOMAC database, developed at the Institute de Recherche pour le Développement (IRD), France [Potier et al., 2005; Potier, 2015, pers. comm.], were also used for the mapping of occurrences of Enoplometopus spp. in the stomachs of pelagic fish throughout the western Indian Ocean.

\section{Results}

A total of six individuals from the genus Enoplometopus were preserved from the stomachs and identified to species. All of them were affected by digestion but their overall state made species-specific identification possible. 

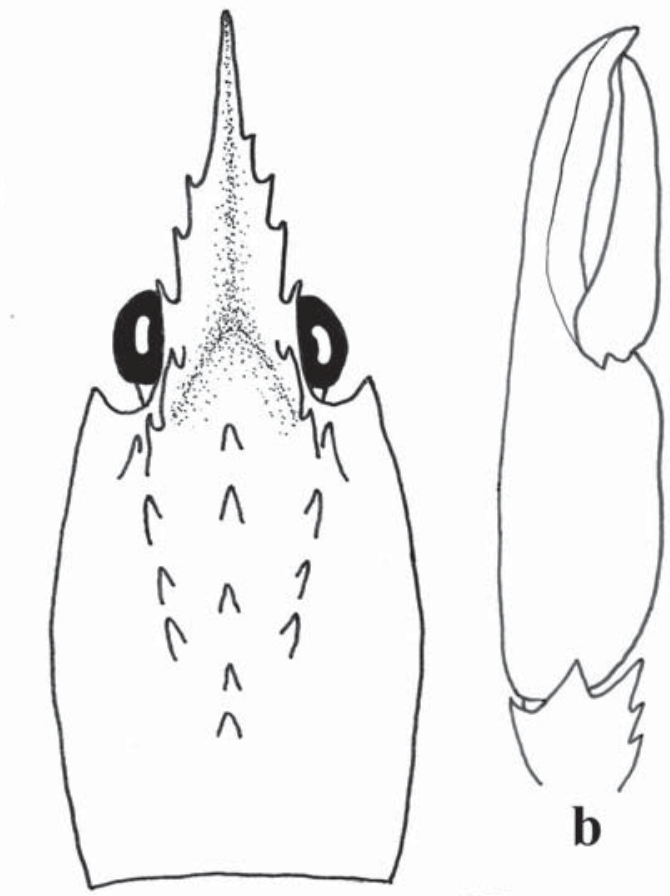

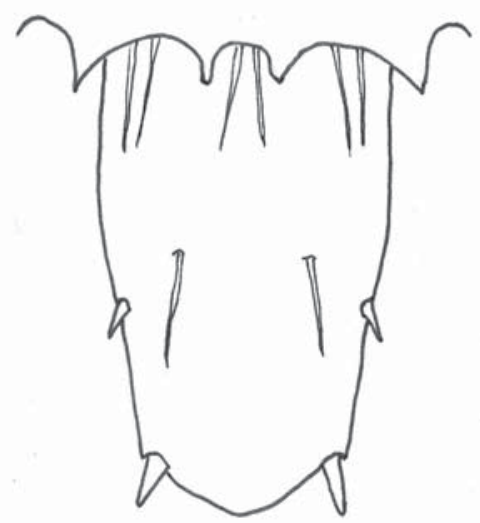

b

C

a
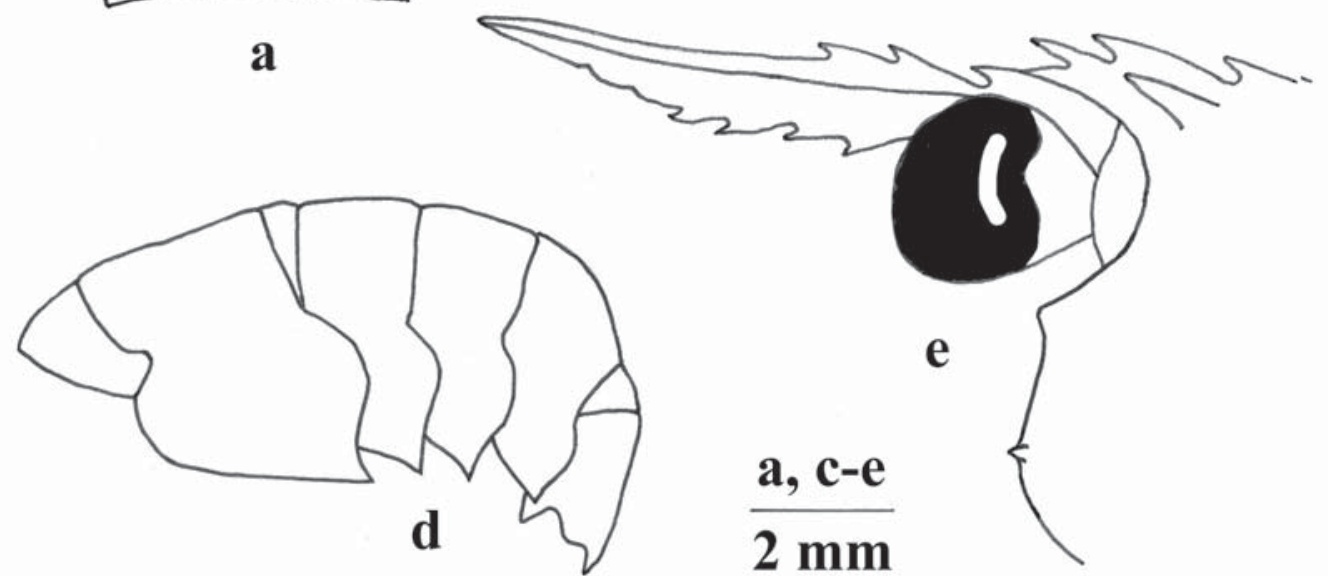

a, c-e

$2 \mathrm{~mm}$

Fig. 1. Decapodid of Enoplometopus pictus A. Milne-Edwards, 1862, specimen RUN-1: a — carapace, dorsal view; b - chela, lateral view; $\mathrm{c}$ - telson, dorsal view; $\mathrm{d}$ - abdomen, lateral view; $\mathrm{e}$ - rostrum and front of the carapace, lateral view.

Рис. 1. Декаподит Enoplometopus pictus A. Milne-Edwards, 1862, экземпляр RUN-1: a - карапакс, вид сверху; b - клешня, вид сбоку; с - тельсон, вид сверху; $\mathrm{d}$ - абдомен, вид сверху; е - рострум и фронтальный край карапакса, вид сбоку.

\section{Systematic account}

Order Decapoda Latreille, 1802

Infraorder Astacidea Latreille, 1802,

Superfamily Enoplometopoidea Saint Laurent, 1988

Family Enoplometopidae Saint Laurent, 1988

Enoplometopus pictus A. Milne-Edwards, $1862^{1}$ Fig. 1.

MATERIAL. Off Reunion Island. RUN-1: Vessel F/V "Parvati”; 11.07.2016, $20^{\circ} 24^{\prime} 53 \mathrm{~S}, 54^{\circ} 16^{\prime} 41 \mathrm{E}$, stomach of Alepisaurus ferox; Geoffrey Bertrand leg; decapodid (carapace length (CL) 6.1

${ }^{1}$ Detailed synonymy and taxonomic description are presented in Poupin [2003]. $\mathrm{mm}$ total length (TL) $22.6 \mathrm{~mm}$ ). RUN-2: Vessel F/V "Marius 3". 5.12.2012, $19^{\circ} 36^{\prime} 49 \mathrm{~S} ; 54^{\circ} 05^{\prime} 26 \mathrm{E}$; stomach of Thunnus alalunga; Loïc Le Foulgoc leg; decapodid (CL $7.2 \mathrm{~mm}$, TL $18.6 \mathrm{~mm}$ ). RUN-

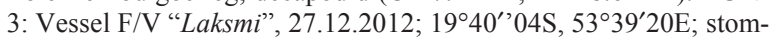
ach of Thunnus alalunga; Alan Sharp leg; decapodid (CL $6.0 \mathrm{~mm}$, TL $19.8 \mathrm{~mm}$ ). Off Mauritius Island. MRU-1: 8.11.2014, 20²'S. $57^{\circ} 16^{\prime}$ E. Stomach of Thunnus alalunga. Zahirah Dhurmeea leg. Decapodid with CL $6.3 \mathrm{~mm}$, TL $26.2 \mathrm{~mm}$. MRU-3: 8.11.2014, $20^{\circ} 12^{\prime} \mathrm{S}, 57^{\circ} 16^{\prime} \mathrm{E}$. Stomach of Thunnus alalunga. Zahirah Dhurmeea leg. Decapodid (CL $6.0 \mathrm{~mm}$, TL $20.0 \mathrm{~mm}$ ).

DESCRIPTION. Rostrum extends beyond scaphocerite's distal margin. Rostrum length from tip to posterior orbit margin $(5.6 \mathrm{~mm})$ almost equal to carapace length from posterior orbit margin to carapace rear margin measured along dorsal side $(6.1 \mathrm{~mm})$. Distodorsal rostrum part, anterior to dorso-lateral teeth flattened and broadens posteriorly. Dorso-lateral rostrum teeth directing outward, positioned 
angularly to dorsal rostrum surface. Thus proximal rostrum part forms groove fringed with three and four dorso-lateral teeth at left and right sides respectively. Ventral rostrum margin keel-like. Rostrum cross-section resembles three-ray star. Ventral rostrum keel margin undulated along anterior part, then forms 4 gradually increasing teeth in middle part. Proximal tooth situated under distal dorso-lateral rostrum tooth.

Two pairs of intermediate spines are present in the area of the rostrum transition into carapace (Fig. 1a). First pair of intermediate spines is situated between the eyes, and second one right behind. Carapace carries pair of supra-ocular spines (positioned above posterior pair of intermediate spines) and three pairs of lateral spines. Distance between lateral spines decreases rearward. Five median spines situated along median line of carapace's dorsal side. First median spine positioned over posterior pair of intermediate spines while last median spine is located at about $30 \%$ of carapace length from its posterior margin. Low keel extends toward carapace's posterior margin behind last intermediate spine.

Carapace surface smooth. Lower part of orbital carapace margin terminated as tiny antennal tooth (Fig. 1e). Branchiostegal spine present. Thin, poorly visible grooves (apparently derivates of cervical and post-cervical grooves) extend from small notch in hepatic part of the branchiostegite, but does not span over carapace's dorsal side. Therefore, cervical groove is absent.

Abdomen smooth, without sculpture. Pleuron of first somite hidden completely below wide pleuron of second somite (Fig. 1d). Anterior margin of pleuron of second somite smooth, skewed backward with pointed ventral margin directed down-rearwards. Pleurons of other somites also pointed but directed downward. Posterior margin of sixth somite armed with two teeth. Telson length is more than 1.6 times its width in widest part (at a proximal one-third of its length). Telson is armoured laterally with two paired spines. The first pair, the smaller one, is positioned slightly beyond the telson midline, with the second and the larger one positioned sub-distally.

Length of first pair of pereiopods almost equal to body length (19.0 and $22.6 \mathrm{~mm}$ respectively). Length of chela (9.8 $\mathrm{mm}$ ) about two times shorter than the entire cheliped; length of fingers $(4.0 \mathrm{~mm})$ about 0.5 of chela length. Chela width is 0.25 of its length. Inner margin of the fixed finger is compressed into a 'blade-like' margin extended toward the distal fingertip, and curved inwardly. Movable finger without bladelike margin. Interior margins of both fingers not serrated but slightly undulated (Fig. 1b).

First pair of pereiopods smooth all along, except the anterior edges of carpus and merus which are armed with four teeth.

REMARKS. Holthuis [1983] divided all species from the genus Enoplometopus into two groups as subgenera Enoplometopus and Hoplometopus that differ by the number of intermediate and post-cervical spines. Poupin [2003], Chan \& Ng [2008], and Chan [2010] proposed to drop such division of the genus. However, here we are following Holthuis' [1983] approach for the convenience of description of decapodids analysed here.

The first group of Enoplometopus decapodids presented in this paper is characterised by the presence of two intermediate spines and a single spine in the middle of the lateral edge of the telson, therefore it belongs to subgenus Enoplometopus Holthuis, 1983 [Holthuis, 1983]. This subgenus consists of five species: E. (E.) pictus A. Milne-Edwards,
1862, E. (E.) occidentals Randall, 1840, E. (E.) chacei Kensley, Child, 1986, E. (E.) debelius Holthuis, 1983, and E. (E.) daumi Holthuis, 1983 [A. Milne-Edwards, 1862; Holthuis, 1983; Kensley, Child, 1986; Chan, Ng, 2008].

Four of them (E. occidentals, E. chacei, E. debelius è $E$. daumi) are characterised by a weakly developed cervical groove and one more or less reduced post-cervical spine. Three distolateral spines (inner pair longest) are also present on the telson in addition to a lateral spine [Holthuis, 1983; Kensley, Child, 1986; Poupin, 2003; Chan, Ng, 2008].

The present specimens are lacking a cervical groove and post-cervical spine, and a telson armed with one lateral and one distolateral spine. All these indicators allow us to identify our decapodids as E. pictus A. Milne-Edwards, 1862.

Adult E. pictus is known from the single specimen (holotype) stored in the Musée National d'Histoire Naturelle (MNHN, Paris) collected in Reunion Island [A. Milne-Edwards, 1862]. Our specimens differ from the holotype by the absence of armament on the outer margin of palms and fingers of chelae, as well as the absence of tubercles on lateral surfaces of palms of the first pereiopods chelae. Apparently, these characters are subjected to ontogenetic variability. Although the telson in the present specimens is longer than wide, according to A. Milne-Edwards' [1862] drawing, the telson' maximal width is almost equal to its length in adults. We therefore suppose that the telson shape and proportions also changing during growth and development.

\section{Enoplometopus holthuisi Gordon, $1968^{2}$} Fig. 2.

MATERIAL. Off Mauritius Island. MRU-5: 5.06.2014, $20^{\circ} 00^{\prime} \mathrm{S}$; $57^{\circ} 27^{\prime} \mathrm{E}$; stomach of Thunnus alalunga; Zahirah Dhurmeea leg; decapodid (CL $8.0 \mathrm{~mm}$, TL $30.0 \mathrm{~mm}$ ).

DESCRIPTION. Distal part of the rostrum absent (broken). Intact proximal part of rostrum does not extend beyond distal eye margin. Ventral rostral keel that (characteristic for E. pictus) absent.

Single pair of intermediate spines present in area of transition from rostrum into carapace. Intermediate spines situated over posterior orbit margin (Fig. 2a). Supraorbital spines located below intermediate ones. Three pairs of lateral spines present on the carapace: posterior lateral spine above hepatic region of cephalothorax. Seven median spines situated along dorsal carapace surface. The first median spine is above intermediate spines while the fifth one is right before the cervical groove. Two posterior median spines are post-cervical.

Carapace surface smooth. Lower orbital edge of carapace terminated by pointed antennal projection. Well-developed branchiostegal tooth also present. Rounded branchiostegal keel extends from branchiostegal tooth to posterior part of branchiostegite but not reaching its posterior margin. Shallow but well visible cervical and post-cervical grooves start from the rear area of the branchiostegite. Both grooves apparently do not extend over the carapace dorsal side. It was impossible to verify this point due to the damaged state of decapodid carapace.

Abdomen smooth, without any sculpture. Pleuron of first somite hidden completely below wide pleuron of second somite (Fig. 2b). Anterior lower pleuron margin of second somite bears small denticles skewed down-rearwards.

${ }^{2}$ Detailed synonymy and taxonomic description are presented in Poupin [2003]. 


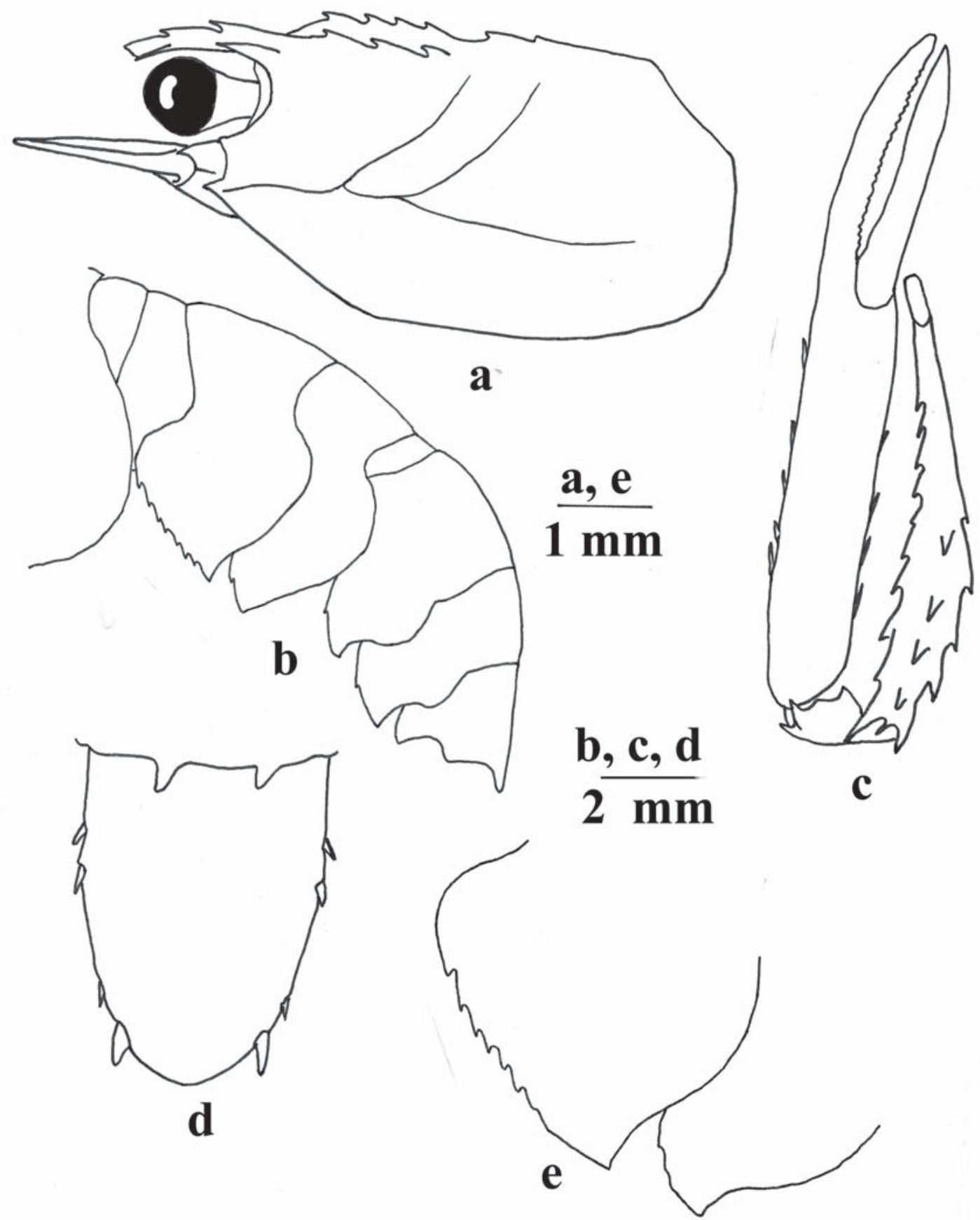

Fig. 2. Decapodid of Enoplometopus holthuisi Gordon, 1968, specimen MRU-5: a - carapace, lateral view; b - abdomen, lateral view; c - pereiopod I; d - telson, dorsal view; e - pleurons of somites II and III.

Рис. 2. Декаподит Enoplometopus holthuisi Gordon, 1968, экземпляр MRU-5: a — карапакс, вид сбоку; b — абдомен, вид сбоку; c - перейопода I; d - тельсон, вид сверху; е - плевроны сомитов II и III.

Pleurons pointed, slightly curving posteriorly. Pleurons of third, fourth, and fifth somites slightly curved backwards, also bearing small denticles over anterior lower margin. Pleuron of sixth somite not pointed. Its posterior edge armed with two teeth. Telson spade-shaped (Fig. 2d). Its maximal width 1.3 times as long as its length. Telson armed with four lateral spines, two of them situated in anterior third of telson and other two situated subdistally. Distal pair of spines notable larger than others.
Length of first pair of pereiopods almost equal to body length (25.0 and $30.1 \mathrm{~mm}$ respectively). Chela long (14.7 $\mathrm{mm})$, exceeding half of pereiopod length. Length of fingers $(6.3 \mathrm{~mm})$ slightly less than 0.5 of chela length. Chela width $(2.0 \mathrm{~mm})$ is 7.5 times its length. Palm edges bear teeth (Fig. 2c). Carpus distal edge armed with three teeth. Edges of merus armed by ten teeth along interior edge, and by five teeth along each exterior and upper edge. 
REMARKS. All Enoplometopus species that possess single pair of intermediate spines, two post-cervical spines and two lateral spines in the middle of the carapace were attributed by Holthuis [1983] to the subgenus Hoplometopus Holthuis, 1983. It includes seven species: E. (H.) antillensis Lütken, 1865, E. (H.) callistus Intés et Le Loeuf, 1970, E. (H.) holthuisi Gordon, 1986, E. (H.) voigtmanni Türkay 1989, E. (H.) crosnieri Chan et Yu, 1998, E. (H.) macrodontus Chan et Ng, 2008, and E. (H.) gracilipes (Saint Laurent, 1988) [Türkay, 1989; Poupin, 2003; Chan, Ng, 2008].

E. (H.) antillensis, E. (H.) callistus, E. (H.) macrodontus, and $E$. $(H$.$) crosnieri are characterised by a single post-$ cervical spine and a wide, relatively short chela. Its length to maximum width ratio varied from 2.4 in $E$. $(H$.) callistus to about 3.0 in other species (extrapolated by RNB from drawn images or photos of the mentioned species presented in Intés, Le Loeuf [1970]; Scelzo \& Rodrigez [1991]; Chan \& $\mathrm{Yu}$ [1998]; Poupin [2003]; Chan \& Ng [2008]).

Proceeding from indicators presented above, the decapodid described here from the subgenus Hoplometopus belongs either to $E$. (H.) holthuisi Gordon, 1986, E. (H.) voigtmanni Türkay, 1989, or E. (H.) gracilipes (Saint Laurent, 1988): all of them are characterised by 2 post-cervical spines and a narrow chela. The ratio of chela width to its length for these species ranges from 5.1 to 6.1 [Holthuis, 1983; Poupin, 2003; Chan, Ng, 2008]. Other species from the subgenus show much lower ratio, however, decapodid described here demonstrate a considerably higher ratio (7.5). Finally the telson shape in all three candidate species is quasi rectangular with slightly rounded distal angles while our specimen has an elongated and rounded telson after a distal pair of lateral spines. Its length to width ratio is 1.3. Apparently, the telson shape is provisional and cannot be used for species identification.

All three candidate species are very close morphologically and are distinguished solely by the coloration of live individuals. Preserved, colourless, E. (H.) holthuisi and E. (H.) voigtmanni differ from $E$. $(H$.) gracilipes by a single character: the absence of spines at the dorsal rear edge of the sixth abdominal somite in the latter species [Poupin, 2003]. E. (H.) gracilipes does not correspond to our decapodid, which is armed with two spines on the sixth abdominal somite.

The distribution range of two remaining candidate species partially overlaps. E. $(H$.) voigtmanni is known in the Indian Ocean from Maldives, Sri Lanka, and Christmas Island; in the Western Pacific it was recorded off Papua New Guinea, Taiwan, Okinawa Island, Ryukyu Islands and apparently Tuamotu (French Polynesia) [Ng, Naruse, 2014]. E. (H.) holthuisi is also a typical Indo-West Pacific species showing, however, much wider distribution. It occurs off Reunion Island (Western Indian Ocean), in Indonesian Waters (Banda and Moluccas Islands), off the Philippines, Marshall (Eniwetok Atoll) and Hawaii Islands, in French Polynesia (Austral Islands: Rurutu), Society Islands: Tahiti; Tuamotu Islands [Poupin, 2003].

Based on considerations presented above, we believe that the decapodid described here belongs most probably to E. (H.) holthuisi: our sample indicates the first record off Mauritius Island, situated in close proximity to Reunion Island where this species was recorded in the past.

Remarks on pelagic predators of Enoplometopus spp. and distribution of pelagic stages

Juveniles of Enoplometopus spp. were recorded in the stomach of three predatory species; albacore tuna,
T. alalunga, yellowfin tuna, T. albacares, and longnose lancetfish, A. ferox. Most of them are from stomachs of albacore tuna (40 records), only five specimens were recovered from yellowfin tuna stomachs and four individuals are from lancetfish stomachs. The size of predators ranged from 68 to $147 \mathrm{~cm}$, their mean size was equal to $103.5 \pm 3.4 \mathrm{~cm}( \pm \mathrm{SD})$ for albacore tuna, $109.0 \pm 24.2 \mathrm{~cm}$ for yellowfin tuna, and $96.8 \pm 35.0 \mathrm{~cm}$ for lancetfish. All predators analyzed here are largesized fish with relatively big mouth gapes, compared with the size of Enoplometopus decapodids. Preying on such small-size macrozooplankton prey like Enoplometopus spp. decapodids tuna apparently use ramfilter feeding [Golet et al., 2015, Romanov et al., 2020] while lancetfish most probably attack their prey individually, as they are ambush visual predators [Romanov, 2002].

Globally, pelagic stages of Enoplometopus spp. were found throughout the tropical zone of the World Ocean in the stomachs of various pelagic species: albacore tuna in Equatorial and Southwestern Pacific (Enoplometopus sp.) [Iversen, 1962; Williams et al., 2014], skipjack tuna, Eastern Tropical Atlantic (Enoplometopus antiltensis) [Dragovich, 1970; Dragovich, Potthoff, 1972], longnose lancetfish, North Pacific Subtropical Gyre (Enoplometopus sp.) [Choy et al., 2013, suppl.]. All these studies reported reef lobsters as occasional rare preys that occur as single individuals in few stomachs. In contrast Enoplometopus spp. are relatively common crustacean prey for albacore tuna in the waters of Reunion Island [Romanov et al., 2020]. It was also recorded in the stomachs of several benthopelagic fish (Etelis carbunculus, Etelis coruscans, Eumegistus illustris, Pristipomoides argyrogrammicus, and Pristipomoides multidens) caught over the outer shelf and slope areas in Reunion Island [Trystram et al., 2015].

Data collected over recent decades, from 2001 to 2016 [Potier, 2015 pers. comm. and our data] shows that juveniles of Enoplometopus spp. occur throughout the south-western Indian Ocean: from Seychelles to Mauritius, from Reunion Island to Madagascar and Mozambique Channel (Fig. 3) [See also Potier et al., 2004, 2007a, b, 2014; Zudaire et al., 2015]. Reunion Island and La Pérouse seamount, situated $\sim 90$ miles north-west of Reunion, are major hotspots of these occurrences.

Besides the waters off Reunion Island, pelagic occurrences of Enoplometopus spp. are mostly situated in proximity to shelves (near Seychelles Bank and off Madagascar Coast), insular areas (Mauritius Island) and seamounts (e.g. in proximity to Travin Bank, $00^{\circ} 26^{\prime} \mathrm{N}, 56^{\circ} 00^{\prime} \mathrm{E}$ ). Few individuals were found in the open ocean, generally downstream from land masses or seamounts. At the same time, extensive sampling efforts throughout the tropical western Indian Ocean shows a general absence of these crustaceans in the open-ocean pelagic environment (Fig. 3). Our data, based on biological samplers, shows that oligotrophic waters of ISSG around the southern Mascarene Islands 


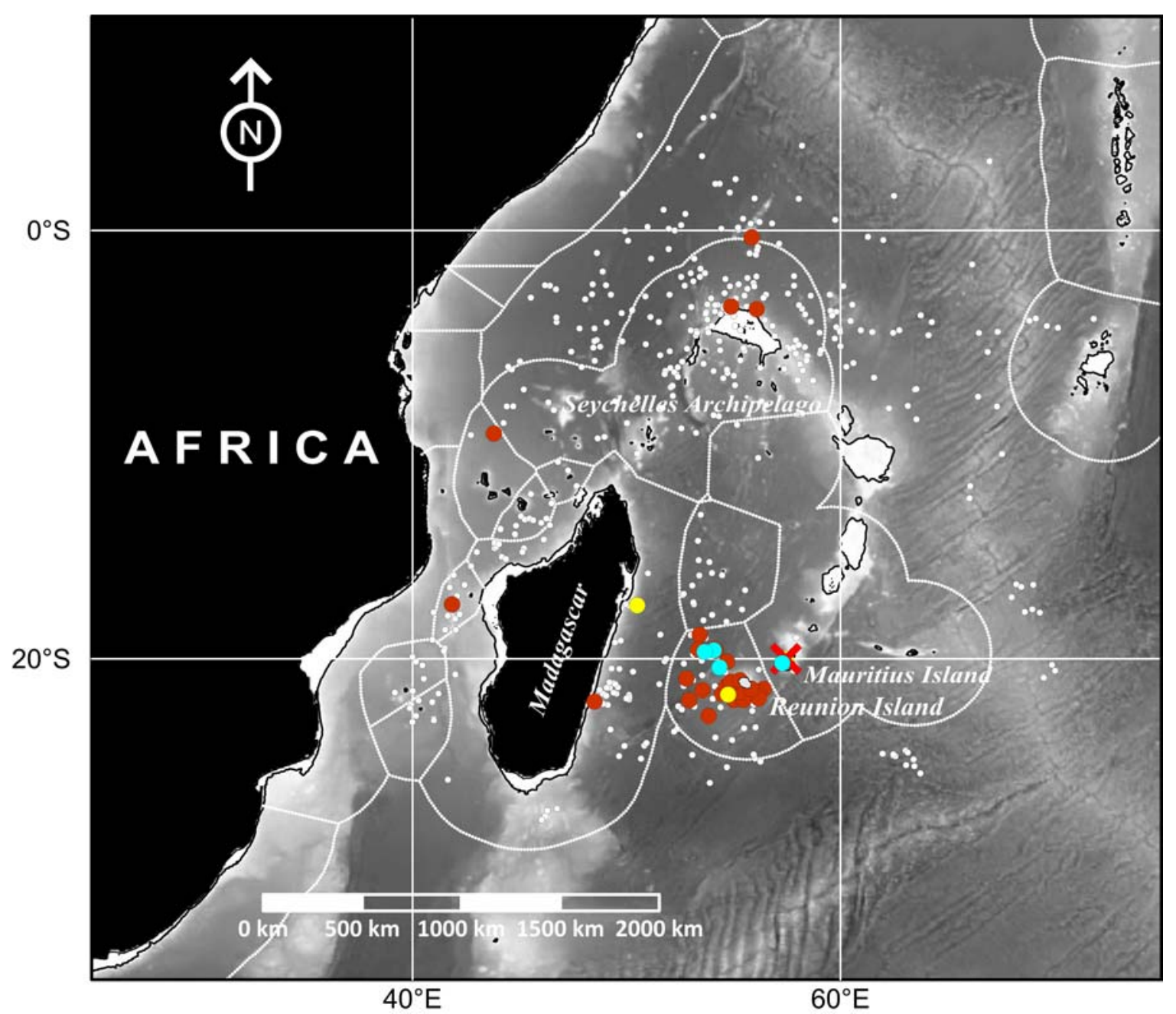

Fig. 3. The geographic positions of stomach sampling and occurrences of Enoplometopus species in the stomachs of pelagic predators collected in the western Indian Ocean (our data and Potier, 2015, pers. comm.). Cyan dots are Enoplometopus pictus, red oblique cross is E. holthuisi, yellow dots are Enoplometopus spp. (our data), brick red dots are Enoplometopus spp (Potier, 2015, pers. comm.) and white dots are pelagic predator's stomachs without Enoplometopus species. Approximate position of the 200-mile Exclusive Economic Zones (EEZs) of coastal states represented by dotted line, the $200 \mathrm{~m}$ isobaths is dark line, and bathymetry from 1000 to $5000 \mathrm{~m}$ (in $1000 \mathrm{~m}$ steps) are shown in greyscale. Coastline and bathymetry data are from GEBCO [GEBCO, 2003, 2016]; EEZs are from FMI [2016].

Рис. 3. Географическое положение точек, в которых брались пробы содержимого желудков пелагических хишников и находок в них видов Enoplometopus в западной части Индийского океана (по нашим данным и Potier, 2015, личн. сообщ.). Голубые точки Enoplometopus pictus, кирпично-красные косые крестики - E. holthuisi, желтые точки - Enoplometopus spp. (наши данные), кирпично-красные точки - Enoplometopus spp (Potier, 2015, личн. сообщ.); белые точки - желудки пелагических хищников без Enoplometopus spp. Примерное положение 200-мильных исключительных экономических зон (ИЭЗ) прибрежных государств представлено пунктирной линией, 200-метровая изобата - темной сплошной линией, батиметрия от 1000 м до 5000 м (с $1000-$ метровым интервалом) показана в градациях серого цвета. Береговые линии и батиметрия из GEBCO [GEBCO, 2003, 2016]; ИЭ3 из FMI [2016].

(Reunion and Mauritius) are characterised by relatively high occurrences of post-larvae stages of two reef lobster species (E. pictus and E. holthuisi) apparently indicating their elevated abundance in coastal areas.

Our results showed usefulness and overall efficiency of top predators as biological samples in the biogeographic and taxonomic studies. This paper confirmed the presence of E. pictus in the waters of Mauritius Island. Past record of E. pictus in Mauritius, reported by Ward [1942], lacked a description of the specimen, and therefore it was doubtful. E. holthuisi is reported from Mauritius Island for the first time. Our study extends documented distribution of both species in the Indian Ocean from single records from Reunion Island onto waters of Mauritius.

\section{Acknowledgements}

The authors want to thank all colleagues involved in specimen collections, in particular Zahirah Dhurmeea, Geoffrey Bertrand, Loïc Le Foulgoc, Thomas Poirout and Alan Sharp. Special thanks to Michel Potier for providing information on occurrences of Enoplometopus spp. collected in predators' stomachs and for data on entire stomach collection. 
Data used in this study were collected during various research projects, in particular THETIS, PROSPER, RAF, GERMON, and EU data collection program DCF-DCMAP. PROSPER Project was funded by EU FEP and by Région Réunion through grant No 34462, GERMON Project "No759 DMSOI/2013" was funded by the European Fisheries Funds EU FEP (Programme Opérationnel des Fonds Européens pour la Pêche) 2013-2015 and EU FEP 2007-2013, Volet Réunion, Axe 3, Mesure 3.6, l'Etat français (BOP 205)) and by Région Réunion. Project RAF was funded by EU FEP and Region Reunion (grant No 38279). Samples collected by scientific observers were supported by the European Union Data Collection Framework (DCF-DCMAP). Collection of specimens in Mauritius was undertaken as part of the $\mathrm{PhD}$ dissertation of Zahirah Dhurmeea which was funded by the 'Allocations de Recherche pour une Thèse au Sud' (ARTS) programme of the Institut de Recherche pour le Développement (IRD). We would like to acknowledge comments and suggestions of an anonymous referee that improved the paper.

\section{Compliance with ethical standards}

Conflict of Interest: The authors declare that they have no conflict of interest

Ethical approval: No ethical issues were raised during our research.

\section{References}

Abrunhosa F.A., Santana M.W.P., Pires M.A.B. 2007. The early larval development of the tropical reef lobster Enoplometopu. antillensis Lütken (Astacidea, Enoplometopidae) reared in the laboratory // Revista Brasileira de Zoologia. Vol.24. P.382396.

Baensch H.A., Debelius H. 1992. Meerwasser Atlas. Melle. Germany. Mergus Verlag für Natur und Heimtierkunde. $1216 \mathrm{~S}$

Chan T.Y. 2010. Annotated checklist of the world's marine lobsters (Crustacea: Decapoda: Astacidea: Glypheidea: Achelata: Polichelidae) // Raffles Bulletin of Zoology. Supplement No.23. P.153-181.

Chan T.Y., Ng P.K.L. 2008. Enoplometopus A. Milne-Edwards, 1862 (Crustacea: Decapoda: Nephropoidea) from the Philippines, with description of one new species and a revised key to the genus // Bulletin of Marine Science. Vol.83. P.347-365.

Chan T.Y., Yu H.P. 1998. A new reef lobster of the genus Enoplometopus A. Milne Edwards, 1862 (Decapoda, Nephropoidea) from the western and southern Pacific // Zoosystema. Vol.20. P.183-192.

Choy C.A., Portner E., Iwane M., Drazen J.C. 2013. Diets of five important predatory mesopelagic fishes of the central North Pacific // Marine Ecology Progress Series. Vol.492. P.169184. https://doi.org/10.3354/meps 10518

Dambacher J.M., Young J.W., Olson R.J., Allain V., Galván-Magaña F., Lansdell M.J., Bocanegra-Castillo N., Alatorre-Ramírez V., Cooper S.P., Duffy L.M. 2010. Analyzing pelagic food webs leading to top predators in the Pacific Ocean: A graphtheoretic approach // Progress in Oceanography. Vol.86. No.12. P.152-165. https://doi.org/10.1016/j.pocean.2010.04.011

Debelius H. 2001. Crustacea Guide of the World. IKAN-Unterwasserarchiv. Frankfurt. 321 p.

Dragovich A. 1970. The food of skipjack and yellowfin tunas in the Atlantic Ocean // Fishery Bulletin. Vol.68. P.445-460.

Dragovich A., Potthoff T. 1972. Comparative study of food of skipjack and yellowfin tunas off the coast of West Africa // Fishery Bulletin. Vol.70. P.1087-1110.

FMI. 2018. Flanders Marine Institute. Maritime Boundaries Geodatabase, version 8. Available online at http://www. marineregions.org/.

GEBCO 2003. IOC, IHO and BODC. Centenary Edition of the GEBCO Digital Atlas, published on CD-ROM on behalf of the
Intergovernmental Oceanographic Commission and the International Hydrographic Organization as part of the General Bathymetric Chart of the Oceans, British Oceanographic Data Centre, Liverpool, U.K.

GEBCO 2016. The GEBCO_2014 Grid, version 20150318. www.gebco.net

Golet W.J., Record N.R., Lehuta S., Lutcavage M., Galuardi B., Cooper A.B., Pershing A.J. 2015. The paradox of the pelagics: why bluefin tuna can go hungry in a sea of plenty // Marine Ecology Progress Series. Vol.527. P.181-192. https://doi.org/ $10.3354 /$ meps 11260

Holthuis L.B. 1983. Notes on the genus Enoplometopus, with descriptions of a new subgenus and two new species (Crustacea Decapoda, Axiidae) // Zoologische Mededelingen. Deel.56. No.22. P.281-298.

Intès A., Le Lœuff P. 1970. Sur une nouvelle espèce du genre Enoplometopus A. Milne Edwards du golfe de Guinée: Enoplometopus callistus nov. sp. (Crustacea Decapoda, Homaridea) // Bulletin du Museum National d'Histoire Naturelle. 2e Série. T.41. No.6. P.1442-1447.

Iversen R.T.B. 1962. Food of albacore tuna, Thunnus germo (Lacépède), in the Central and Northeastern Pacific // Fishery Bulletin. Vol.62. No.214. P.459-481.

Kensley B., Child A. 1986. A new species of Enoplometopus (Thalassinidea: Axiidae) from the Northern Philippines) // Journal of Crustacean Biology. Vol.6. No.3. P.520-524.

Longhurst A. 2007. Ecological geography of the sea. 2nd edition. San Diego, CA: Academic Press. 542 p.

Martin J.W., Davis G.E. 2001. An updated classification of the recent Crustacea // Natural History Museum of Los Angeles County, Science Series. No.39. Los Angeles, California. 123 p.

Martin J.W., Olesen J., Høeg J.T. 2014. Atlas of Crustacean Larvae. Johns Hopkins University Press. Baltimore. 385 p.

Milne-Edwards A. 1862. Faune carcinologique de l'Île de la Réunion // Maillard L. (ed.). Notes sur l'Île de la Réunion (Bourbon). Dentu, Paris: Annexe F. P.1-16.

Ng P.K.L., Naruse T. 2014. The lobsters of Christmas Island and Cocos (Keeling) Islands, with new records of Palinurellus wienecki (De Man, 1881) and Enoplometopus voigtmanni Türkay (1989) (Crustacea: Decapoda: Palinuridae: Scyllaridae: Enoplometopidae) // Raffles Bulletin of Zoology. Supplement No.30. P. $305-312$

Potier M., Lechauve J.-J., Bard F.-X., Sabatie R., Ménard F. 2005. STOMAC: a database for storing information on stomach contents // ICCAT Collective Volume of Scientific Papers. Vol.58. No.5. P.1662-1674.

Potier M., Marsac F., Lucas V., Sabatie R., Hallier J.-P., Ménard F. 2004. Feeding partitioning among tuna taken in surface and mid-water layers: the case of yellowfin (Thunnus albacares) and bigeye (T. obesus) in the western tropical Indian Ocean // Western Indian Ocean Journal of Marine Science. Vol.3. P.51-62.

Potier M., Marsac F., Cherel Y., Lucas V., Sabatie R., Maury O., Ménard F. 2007a. Forage fauna in the diet of three large pelagic fishes (lancetfish, swordfish and yellowfin tuna) in the western equatorial Indian Ocean // Fisheries Research. Vol.83. P.60-72.

Potier M., Ménard F., Cherel Y., Lorrain A., Sabatié R., Marsac F. 2007b. Role of pelagic crustaceans in the diet of the longnose lancetfish Alepisaurus ferox in the Seychelles waters // African Journal of Marine Science. Vol.29. P.113-122. http://doi.org/ 10.2989/AJMS.2007.29.1.10.75

Potier M., Bach P., Ménard F., Marsac F. 2014. Influence of mesoscale features on micronekton and large pelagic fish communities in the Mozambique Channel // Deep Sea Research Part II: Topical Studies in Oceanography. Vol.100. P.184-199. http://doi.org/10.1016/j.dsr2.2013.10.026

Poupin J. 2003. Reef lobster Enoplometopus A. Milne Edwards, 1862 from French Polynesia, with a brief revision of the genus (Crustacea Decapoda, Enoplometopidae) // Zoosystema. Vol.25. No.4. P.643-664.

Romanov E.V., Zamorov V.V. 2002. First record of a yellowfin tuna (Thunnus albacares) from the stomach of a longnose lancetfish (Alepisaurus ferox) // Fishery Bulletin. Vol.100. P.386-389. 
Romanov E.V., Nikolic N., Dhurmeea Z., Bodin N., Puech A., Norman S., Hollanda S., Bourjea J., West W., Potier M. 2020. Trophic ecology of albacore tuna Thunnus alalunga in the western tropical Indian Ocean and adjacent waters // Marine and Freshwater Research. Vol.71. No.11. P.1517-1542. https:// doi.org/10.1071/MF19332

Scelzo M.A., Rodrigez G. 1991. Nuevo registro de la langosta Enoplometopus antillensis Lütken, 1865 (Crustacea Decapoda, Enoplometopidae) en aguas marinas Venezolanas, con notas sobre la coloración del animal en vivo // Memoria de la Fundación La Salle de Ciencias Naturales, Vol.51. No.135136. Contribución No.156. P.225-233.

Saint Laurent M., de. 1988. Enoplometopoidea, nouvelle superfamille de Crustacés Décapodes Astacidea // Comptes rendus de l'Académie des Sciences Paris. Biologies, T.307. Série III. P.59-62.

Trystram C., Roos D., Guyomard D., Jaquemet S. 2015. Mechanisms of trophic partitioning within two fish communities associated with a tropical oceanic island // Western Indian Ocean Journal of Marine Science. Vol.14. P.93-111. http:// doi.org/10.1093/icesjms/fst034
Türkay M. 1989. Enoplometopus (Hoplometopus) voigtmanni n. sp., ein neuer Riffhummer von den Malediven // Senckenbergiana Maritima. Bd.20. No.5/6. S.225-235.

Ward M. 1942. Notes on the crustacea of the Desjardins Museum, Mauritius Institute, with descriptions of new genera and species // The Mauritius Institute Bulletin. Vol.2. No2. P.49-113.

Williams A.J., Allain V., Nicol S.J., Evans K.J., Hoyle S.D., Dupoux C., Vourey E., Dubosc J. 2014. Vertical behavior and diet of albacore tuna (Thunnus alalunga) vary with latitude in the South Pacific Ocean // Deep-Sea Research Part II: Topical Studies in Oceanography. Vol. 113. P.154-169. http://doi.org/ 10.1016/j.dsr2.2014.03.010

Zudaire I., Murua H., Grande M., Goñi N., Potier M., Ménard F., Chassot E., Bodin N. 2015. Variations in the diet and stable isotope ratios during the ovarian development of female yellowfin tuna (Thunnus albacares) in the Western Indian Ocean // Marine Biology. Vol.162. P.2363-2377. https://doi.org/ 10.1007/s00227-015-2763-0

Responsible editor V.A. Spiridonov 